\title{
Monika Sokół-Rudowska*
}

\author{
US AMONG THEM. \\ A STUDY OF THE CONTEMPORARY \\ POLISH EMIGRATION TO NORWAY
}

\begin{abstract}
A significant increase in migration from Poland has been observed since Poland joined the European Union in 2004. It has mainly been labour migration to richer countries of Western Europe. The rate of migration has exceeded the expectations of both politicians and experts. Statistics now show that about 2 million citizens have left Poland since that moment (Główny Urząd Statystyczny 2011). One of the top countries which Poles choose as a target for migration is Norway. Not only do the majority of Polish immigrants lack basic skills in Norwegian, but they also lack basic skills in English. The communication problems with people who don't belong to $u s$, those who use the same language, is one of the most important factors that contributes to the creation of closed Polish ethnic enclaves. These communities try to rebuild their own identity in new countries based on the traditions and cultural codes brought from Poland, and us-them as opposite values. In this case us designates those members of a Polish minority in Norway, who follow norms accepted by the group, while Norwegians here represent them. A confrontation with the antagonists certifies one's own ideas and values. It is worth noticing that not all Polish migrants live within their ethnic groups. Poland is a rather culturally homogeneous country. This is a factor which facilitates finding one's own ethnic group in a foreign land and thereafter establishing one's place in it. Living abroad, however, changes one's identity due to foreign influence. The identity of them changes similarly, depending on the situation. After a preliminary categorization of all the Poles as us, gradual divisions and categorizations take place within the Polish immigrant community. A significant number of Poles, usually less educated, often deliberately choose to isolate themselves from the culture of the host country. They use it as a method of retaining their own culture. Families and friends are brought from Poland in order to reproduce the lost local homeland.
\end{abstract}

Key words: migration, Poles, Norway, us-them, integration

\section{INTRODUCTION}

Migration has been occurring for the last two centuries in the Polish tradition, since 1795. The first wave of emigration to other countries was noted after the November Uprising in 1830 when a significant number of Polish natives left the country without the possibility of return. Similar phenomena have been recurring in Polish history with lesser or greater intensity up to the present day. Paweł Boski has even gone so far as to claim that Poland is the most migrant society in Europe (Boski 2010).

\footnotetext{
* Opplandsarkivet avdeling Maihaugen in Lillehammer, m.sokol.rudowska@gmail.com
} 
Migration is quite a specific social process with a noticeable distinction between the us and the others. The aim of this study is to present the antagonism from the minority point of view, where the us is represented by the Polish immigrants in Norway and the others relates to the citizens of Norway with an ethnic Norwegian background. Such specificity seems to be indispensable due to the fact that Norway, as a multicultural country, holds a significant percentage of citizens with different ethnic and cultural backgrounds, who often do not identify themselves with their new homeland, its culture and tradition.

The article has been written on the basis of materials gathered during three international projects (including migration from Poland), whose aim was to learn about migration to the country of Norway as a whole or to its specific parts. Being one of the largest ethnic groups, Poles have played a significant role in the research process. In 2008 they led the statistics relating to the size of particular immigrant nations in Norway (Norsk statistisk sentralbyrå 2009) and they are still in the leading position today (Norsk statistisk sentralbyrå 2012).

The data were obtained through interviews conducted with Polish immigrants in Norway, with those immigrants who have returned to Poland, and with families of immigrants residing in Norway. About 70 such interviews have been collected. Other significant tools in the study were the active observation of the Polish immigrant community in Norway together with research of archival source materials.

\section{IDENTITY AS A MARKER OF CULTURE BOUNDARIES}

A very important issue in the immigrant society is the distinction between $u s$ and them, which has been defined on the basis of Fredrick Barth's culture boundaries described as mental divisions located in the human consciousness - an outcome of the actions of a particular community to construct and maintain them. It is those boundaries that according to Barth separate us from them (Barth 1969; Grzymała-Kazłowska 2007). Moreover, they may be marked by a sense of identity and group membership, which in turn is delineated by elements of selfconsciousness distinguishing the Self from the Others (Benedyktowicz 2000; Obrębski 1936). It is the others/them who enable one to recognize one's own authenticity by experiencing uniqueness, otherness resulting from the need for self-definition (Znaniecki 1931). Identity is shaped under the influence of, in relationships with, and contact with the other (Oles 2008). In consequence, relations with the other are quite complex and multilayered, and result from the need to have an antagonist, the confrontation with whom would uphold one's own ideas and values (Mazur and Wawrzyczek 2010).

Just like us, the women in Poland, every day they must cook dinner and bake a cake at the weekend. But the other women here, no. They've always looked at me as if I were from another planet and thought "you have shops, so you can buy everything". Cleaning is also another story. We all [Polish women] clean on Saturdays, but they don't. They've got cleaning ladies who take care of the house, so they can afford everything, to go on trips, holidays. They don't care about such things, as we do here, in Poland, you know, about all these material things. Here, for them simply having free time counts most (Edyta). 
Identity is shaped by the knowledge of, and following, those norms and rules maintained in a particular tradition which are usually difficult to define (Bokszański 1997). A new member of the migrant community usually learns the rules governing a particular group through active participation and observation. People who introduce a new member to a group cannot always precisely describe them, since they themselves often are not fully aware of all such rules or boundaries which are identified by the community members through various inherent cultural codes and values. This results in the $u s$ group being a highly insular society.

That's what Internet's for, I mean the Norwegia.net forum where you can find lots of ads, advice on how to be an immigrant. [...] They said: "listen, you want to buy this, so go to that shop, and not to this one because it's expensive". And what I found in those microsituations and those microcontexts of the everyday life is that I simply behaved the way they'd told me. In other words, I've been socialized to become a true immigrant $\left(\right.$ Marek $\left.^{1}\right)$.

According to Boski, identity cannot be established without in-group comparisons. It specifically pertains to positive identity with the striving for $u s$ to be better than them and, consequently, taking great pride in the obtained results (Boski 2008). Many times in conversation Poles clearly manifest their superiority over Norwegians, referring to a more dignified historical background, richer culture, a more educated society and greater diligence.

[They are] simple people. To me, if it weren't for the oil and gas, it would be much worse here now than in Poland a few years ago. And really they, the people in Poland, are far more educated than Norwegians. At least they know where Norway is, and Oslo. But not every Norwegian can point to Poland or Warsaw on the map (Krzysztof).

Interestingly, such manifestation of views rarely occurs outside one's own group boundaries.

In some cases these beliefs may turn national pride into megalomania, where one's own group is thought to be the centre of the world together with a conviction about its superiority and nobility (Benedyktowicz 2000). Polish immigrants often stress the unique complexity of their mother tongue in comparison to other Western European languages. Such claims often are not supported by true knowledge, since a significant majority of Poles in Norway does not speak any foreign language (Sokół-Rudowska 2010). National megalomania is also characterised by a specific way of ranking values and ideas - those that come from us are a sign of genius, whereas the same notions shared by the other group are denigrated and deemed negative (Bystron 1980). Janusz Tazbir in reference to the $18^{\text {th }}$-century Polish society described the national megalomania and a strong messianic trend present at that time as a kind of "silencer" of the social anxiety and sense of inferiority in relation to the other (1978). This observation has not lost its meaning in the 21 st century. Polish immigrants themselves, often without any objections, accept the social position delegated to them by the Norwegian citizens. Many of them are aware of the fact that this often means being a member of a second-class

\footnotetext{
1 Marek is a cultural anthropologist who has done research on the identity of Polish immigrants living in Oslo.
} For a short period he lived and worked with them while conducting observations. 
social group. The potential benefit leads them to accept their position in the society with little chance of moving up in the social ladder.

Sometimes cultural boundaries are established around concepts referring to sanctity and transcendence such as God or Reason (Bokszański 1997). Part of the Polish society in Norway identifies itself with Catholicism and associated traditions which they have brought with them from Poland. These beliefs serve to stand in opposition to the official Protestantism of Norwegians and their laicisation. In some cases Polish Catholicism takes quite radical forms, such as the Regnum Christi association which defines itself as a Faith Propagation Movement, obligated to fight for Christian values in the political life of Poland and Europe. In reality Regnum Christi not infrequently invokes anti-Semitic slogans and propagates values and attitudes of the radical right (Kulas 2012; Skogsrad 2012).

\section{WHO IS US AND WHO IS THEM?}

Regarding basic norms, values, archetypes and cultural traditions, Poland is rather culturally homogeneous in comparison to other European countries (Mucha 1999). It is a factor which facilitates finding one's own ethnic group in the foreign land and establishing one's place in it. Meanwhile, in order to define the surrounding reality and assert their identity, the migrants often use the popular us-them stereotype to oppose the known against the unknown. The main indicator of the $u$ s familiarity is language, which helps to verify group membership quite easily (Benedyktowicz 2000). Having difficulty in learning the local tongue, the migrant society in Norway prefers to mingle with their own ethnic group, where no problems with verbal communication exist (Sokół-Rudowska 2011).

They don't want to mix with us. Maybe the problem is also that I don't know their language. Maybe it'd be different if I spoke the same as them. I speak Polish with Poles, so I should speak Norwegian with them. Maybe I'd have more friends then. The language is the burden (Krzysztof).

It is also worth mentioning that due to linguistic similarity and thus easier communication together with a similar cultural background, Slovakian immigrants are often included as members of the us group.

Identity is not a stable value. Among immigrants living abroad for a longer period of time, one can observe a gradual change of identity, resulting from constant overlapping of values from different culture fields (Oleś 2008). This leads to an implication that the image of them is as changeable and transitory as one's own identity (Bauman 2000). The same people in one situation are perceived as us while in other they become them. This means that them/ the other/foreign is not an objective, but a rather a subjective indicator of group membership (Bartmiński 2007). At first, a Pole in a foreign country is automatically treated by the fellow compatriots as $u s$, no matter the region or community of origin. The situation changes when a group member often unwittingly breaks the existing rules and fails to comply with them. This results in loosening of ties with the us fellows, who start to feel apprehensive about the member. He/she is neither totally with us nor completely with them. 
Relationships between family members and friends must also be taken into account, where there is greater loyalty than to a common ethnic group. The Polish immigrants are not a homogeneous society, which can be observed in the example of the gap between the old and the new immigration. The former consists of people who emigrated to Norway as political refugees in the 1980s, forming quite a cohesive group, whose members are highly educated, fluent in the Norwegian language, politically active citizens having developed close relationships with the Norwegians. They differ from the modern income-oriented new immigration of people with low education, sharing such different values that they do not feel a special bond with this group.

Despite the fact that Poles even abroad are seen to display racist behaviour, according to the study of Monika Biłas-Henne (Biłas-Henne 2011) members of particular ethnic groups residing abroad are more willing to mingle with people from their own group and, in second place, with members of other immigrant ethnic groups, who act as a multicultural buffer that stands between us and them, the natives. Other ethnic groups are considered as them (foreigners) by the native citizens, which presents a value of being less them or even more $u s$, especially when there is a similarity of language and culture (e.g. Slovakians, Ukrainians).

\section{POLES IN NORWAY - US AMONG THEM}

Norway is a multicultural country, where over 700 thousand citizens are immigrants. In a country populated by about 5 million people, they constitute as much as $12,2 \%$ of the total population. There are 60 thousand Poles living in this cultural mosaic. What is more, for years they have constituted the most abundant group of foreigners living in Norway (Norsk statistisk sentralbyrå 2012a).

Migration in itself has many aspects, since decisions to emigrate have various underlying reasons such as political, economic, family, social, cultural and demographic situations (Dębowska 2007). Research proves that the phenomenon of international migration is closely connected with the modern global economy (Kłos 2006).

Norway is considered as a country hospitable to immigrants, especially because they play an important role in the country's economy; local manpower is not sufficient to answer increasing needs (Tiersland 2012; Braathen 2011). It is a post-modern country, which prefers to act according to the notion that the other cannot be eliminated; therefore, in order to maintain social stability, it is best to accept their otherness (Bauman 2000). In contact with the culture of the host countries this otherness of Poles stems out of the need to be seen as an Eastern European, as opposed to Western European cultural identity (Mazur and Wawrzyczek 2010) or, in this case, Norwegian ethnicity. Poles often describe themselves as spontaneous people, who are quite emotional and extrovert, which stands at odds with the characteristic features of Norwegians - polite, but closed and aloof. Such discrepancy is often the cause of problems Poles have with accurate interpretation of foreign, Norwegian social codes of conduct. 
Norwegians are very kind people, but once you meet them, it turns out that these kind smiles and very polite behaviour aren't always honest. As I've said, the people I've met on my way treated me as a complete stranger and didn't want to meet me. And that's the most upsetting, because we're not inferior people. We're the same as other nations and it seems to me that we shouldn't be treated as inferior. I'm not a bad woman. I didn't hurt anyone and I think it isn't fair to be treated like that (Katarzyna).

They differ in mentality, for example. It seems to me that they are more even-minded. For example when they work, they work and when they relax, they relax. A Pole cannot do that, just simply mellow out. I don't know what the cause of this is. What I know is that you can't drop by to pay someone a visit, I'm talking about Norwegians. You must arrange a meeting first. In Poland, however, you can pop in without making special prior arrangements. In our country drinking alcohol is more visible. Here it's more hidden or done in secret, but I know they drink, because I've seen them. They drink a lot. But you can't see it in the streets. They try not to display this too much (Wojciech).

In line with the research conducted in the Netherlands (Toruńczyk-Ruiz 2010), one can say that the Norwegian society sees Poles as a single, cohesive group, laborious, likely to form small enclaves, distancing themselves from the natives and excessively drinking alcohol. What's more, the Norwegians (with good reasons) think of Poles as potential smugglers, mainly of alcohol and cigarettes (Andreassen 2012; Eriksen 2012), and also as people "with little dignity" (a cheap labour force), working for very low wages, which Norwegians deem offensive. Moreover, Poles often work overtime, and often being unaware of their rights, they get cheated by dishonest employers (Renda 2010; Gulldahl 2012; Nederba 2012).

I've worked on a farm with animals, hens. I also helped the farmer in building a new barn, renovate the old one. The work there finished in November, so I found work as a driver for a guy who cooperated with a bakery. Unfortunately he turned out be dishonest and didn't pay my wage. I had to beg for it. I decided to hand the case over to the police and they delegated it to the labour court, where of course I won and he had to return everything... (Adam).

It is natural for migrants of the same ethnic origin to form groups (Toruńczyk-Ruiz 2010), which influences the lifestyle of its particular members and demands adjustment to the governing norms (Toruńczyk-Ruiz 2010). The main elements which help to maintain group cohesion and self-define its members include: symbolism as deeply rooted and publicly approved cultural knowledge, language in its cognitive and paradigmatic function, as well as axiology related to the values and everyday practices in all spheres of life (Boski 2010). Polish immigrants in Norway share a specific lifestyle constituted by a group of habits and routines building the whole group, within which the migrant feels secure. It is quite different from the Norwegian lifestyle, where concentration on pleasure, comfort and consumption contrasts with the Polish work ethos, frugality, and a readiness to make sacrifices for one's family. The otherness of the reality in which they are to live is also highlighted by Poles' lack of intercultural experience and poor knowledge of foreign languages (Toruńczyk-Ruiz 2010).

However, it happens that this otherness and cultural difference is maintained consciously, so as not to disturb the relations within a wider socio-cultural network (Benedyktowicz 2000). Polish migrants often choose cultural separatism in order to uphold their own culture, disregarding the culture of the host/receiving country (Boski 2010). 
Being there in Norway, they treat the country in a purely pragmatic way, the only thing that counts is work. It's not important for them to form relations with the Norwegian society (Marek).

For about 20 years they've been working in construction, earlier in Germany or someplace else. They had perfect skills, but didn't know the language at all. They've invented their own mixed language and that is how they communicated with the management. But how they managed to get their messages across, I really don't know. It was funny what it all looked like. [...] But when I spoke with the bosses and they said they usually didn't have a clue what those workers wanted to say. They only nod because they see that something's going on, but have no idea what. They see that the job's running, so they nod and leave. And even though they've been working here for so long, they refuse to learn the language. [...] They said that they weren't going to learn anything, the bosses could learn Polish instead (Tomasz).

The specifics of chain migration, where the departure of one person starts a wave of migration among the family and friends is reflected in the urge to reproduce the lost local homeland (Appandurai 2005). Bringing one's relatives and friends from Poland helps to make the space more familiar, and build a buffer of us-ness/familiarity.

My family has been here before, that's the main reason why I came here, and my sister helped me find a job. Yes, I didn't go in the blind, but I'd already had a place that was waiting for me (Adam).

My brother-in-law's sisters had been living in Norway for several dozen years, and the rest just came one after the other. My brother-in-law emigrated first, then my sister followed him and she brought me here (Dorota).

A community of compatriots gives migrants support and a feeling of security (ToruńczykRuiz 2010).

We talk, eat something nice. Once a week we have a party with some alcohol, [...] we laugh, sometimes dance. Just a friendly social meeting. We have small talk about everything and nothing (Krzysztof).

According to Boski, Poles feel alienated without the support of their 'fellow comrades', which may lead to depression and alcohol abuse (2010).

Despite obtaining some harmony of life between us and them in Norway, visible conflicts do happen, resulting from culture clashes and misunderstanding of mutual values or sometimes even as an act of opposition against the rules governing the other group. One of such conflict ignition points is childcare. Norwegian law gives the Barnevernet, which is a national institution, the right to far-reaching intervention in family issues (Barnevernet 2012), even when circumstances for taking such action are not based on sound evidence. In some cases this results in children being taken away from their parents and located in a foster family, which sometimes may lead to the separation of siblings. In 2011, the parents of over eight thousand children lost their parental rights because of Barnevernet intervention (Norsk statistisk sentralbyrå 2012b). The biological parents can see their children once every few months under strict control of the Barnevernet authorities (Witoszek 2012). Such far-reaching interference in family matters cannot be understood by the Polish parents and 
the Polish society in Norway. For them it is against all known norms. The institution which deprives the child of its family in the name of good will, 'because it came to school with a sad face', and then delegates the child to strangers, who often do not speak its language, is seen as negative and unacceptable. Conflict with Barnevernet does not only involve Poles, but also other ethnic groups residing in Norway (Olsen 2012). Cultural differences and lack of will of the national authorities to find common ground emphasize this otherness and often lead to personal tragedies. Such situations generate extreme action taken up by the parents, who sometimes kidnap their children to steal them away from their foster families (Adamowska 2011).

\section{AN IMAGE OF THE US GROUP REPRESENTATIVE}

The vast majority of Polish migrants in Norway constitute men (Norsk statistisk sentralbyrå 2010), who find employment mainly in the building industry (Friberg and Tydlum 2007). In January 2011 the Central Statistical Office in Norway noted around 13 thousand men with Polish citizenship between the most productive working age period of 30-39, and only 5 thousand women in the same group. Polish females usually work in the services sectors as cleaners (Trygstad et al. 2011). The Norwegian employers are more willing to hire Poles, being a highly-qualified, but also cheaper and more dedicated labour force (Nygaard 2011; Oddvin 2011; Michalsen 2011).

A majority of migrants are employed as non-qualified workers in professions which seem unattractive to Norwegians due to low wages, job prestige and high arduousness. This means that Norway is almost completely dependent on foreign employees (Tiersland 2012). Having decided to work abroad, migrants must usually take into account the possibility of professional demotion, working below their qualifications on a much lower position. The otherness of the environment in which they have found themselves in is highlighted by a feeling of a dramatic fall in social status.

The Poles' lifestyle, great diligence, and lack of balance between work and free time are defined by disharmony in life. This often results from the fact that a Pole working in Norway spends most of their earned money on self-maintenance and delegates a sum to the family in Poland. Entertainment, which is quite expensive in Norway in comparison to Poland, seems out of reach.

But those immigrants are quite an interesting group, because they stay there for three weeks, then they return for ten days to Poland, where their social identity changes, where, on one hand they must make a lot of sacrifices in Norway, they can't afford many things. And, on the other, in Poland they can afford to go on different trips or for dinner to more expensive restaurants (Mark).

In Vinstra, a pub, a disco pub where we often met [...] I spent my money, but later I decided to set something aside and I stopped going there, because a beer cost about 50 PLN. And I remember that once I went with a girlfriend to a disco in Oslo, where I paid I think about 120 PLN for a cola with a little whisky, and after that night I stopped having fun this way (Tomasz). 
The attitude to work and play is one of the key features that distinguishes Poles from the natives in Norway, who also do not care for balance in life, but for them it is the other way round, as entertainment and pleasure play an important part in their lives.

Poles are proud of their typical Polish values such as close relationship with family, hospitality and spontaneity (Toruńczyk-Ruiz 2010), but a common image of the Polish immigrant is a constant longing for their relatives and elements of Polish culture or reality which could not be found in the receiving country.

The biggest problem is the fact that [...] there is no family here. You always had grandmas, grandpas, parents, cousins dropping by or on occasion a brother, one or the other with his wife or girlfriend. We met and it was nice. There was a warm family atmosphere. And you know, friends, however nice they were, you always miss your family, and people who have never been so far away from home can't understand this. They can't understand this and they don't know how hard it is sometimes (Katarzyna).

\section{NOT TOTALLY US BUT NOT COMPLETELY THEM}

However, not every migrant identifies with his/her ethnic group and wants to be seen as ours. Despite being seen as a coherent ethnic group, Poles are aware of the fact that they lack inner solidarity. They consider it to be one of the features distinguishing the Polish social group from other migrant ethnic groups (Toruńczyk-Ruiz 2010). Some Polish immigrants do not want to subordinate to their ethnic group and reject the values maintained by it, since they feel ashamed of the behaviour presented by their compatriots. Polishness as a unifying category can cause problems with self-identification in terms of social class, education or identity (Garapich 2010).

But when I returned and noticed I had dirty shoes, standing in the subway I looked at those shoes and said: "Oh my God, now everyone here thinks I'm a Pole. This is definitely a Pole, who came here for money, who drinks a lot etc." And this is fantastic, I caught myself taking out a notebook and writing notes, what I'd observed during that renovation. And I was doing it just to show them that I was writing something down here (Marek).

Migrants working in more "prestigious occupations", standing a bit higher on the social ladder, tend to shy away from the typical migrant community. They distance themselves from the lifestyle and behavioural patterns represented by their unskilled compatriots (Toruńczyk-Ruiz 2010).

Some Poles strive to break the us-them antagonism, trying to soften the boundaries of this division. Usually the language is the key to this social integration with the natives, giving immigrants a chance to form relations with Norwegians not only at work but also on social grounds. Thanks to language, Poles learn about the traditions and social codes of the host country. They acquire a new culture, bridging the gap between their native and the newly acquired customs. 
How can you live here and not know the language? I don't understand this. I have friends, a friend who has been living here for 10 years now and doesn't know a word. But it's their choice. Above all this isn't only about work. You have to go out, go to a shop, an office, a party, deal with something. How can you do this without the language? It's impossible. You can't live in a foreign country not knowing the language (Eliza).

In most cases these immigrants take advantage of the acquired skills professionally, working as translators/interpreters or bilingual teachers of Norwegian for Polish children. They go out of their own group and reach into the other; consequently they aren't the same anymore, but become contaminated with new values and ideas. Meanwhile as domesticated foreigners, due to the highly hermetic nature of the migrant society, for the natives they constitute a major source of potentially inaccessible knowledge about the biggest ethnic group in the country, which is slowly becoming an important part of Norwegian society and especially of the country's economy.

Children constitute a very interesting not-us but not-them group, who have either come to Norway in early childhood or have been born in this country. These children are constantly balancing between these two cultures - the Polish one at home and Norwegian outside. Being in constant presence of the Norwegian educational environment and forming close relations with their Norwegian peers at school, they take over the values and culture codes of the host country. When children live under the influence of the Norwegian culture from their early childhood, despite having Polish parents, they identify themselves as Norwegians. Not infrequently, the third generation of Polish immigrants does not speak Polish. In the eyes of the migrants' children the culture of the parents becomes foreign, their culture in the eyes of the migrants' children (Boski 2010; Phinney 2003; Liebkind 2006).

\section{CLOSER TO US}

Zbigniew Benedyktowicz, in line with Florian Znaniecki's theories, claims that establishing hierarchy within the notion of otherness can become a trap, since depending on the situational context the same person or group might be seen one time as us and another time as them/ the other. In his view it is impossible to contrast racial and anthropological differences with national and cultural ones (Benedyktowicz 2000). However, in relation to international and intercontinental migrations, one cannot take into account only the differences mentioned above. Africans stand out from the Norwegian society not only by their skin colour, but even more distinctively with their culture and a specific perception of reality. Not infrequently, despite having Norwegian citizenship, they maintain their own cultural values and identify themselves with the origin country. In Norway, just as in Great Britain, Polish migrants are perceived in a specific way, as white Christians, who despite being members of an Eastern European country, belong to the Western European culture. Therefore, in spite of many differences, they can easily read the common European socio-cultural codes of behaviour. Therefore, they are not quite as other as others. Poles constitute a kind of buffer against the unknown, thus dangerous others, who are usually of Islamic origin and a different race. The image of a Pole seems closer to us and more acceptable in the mosaic of ethnic groups which form a multicultural country (Garapich 2010). 


\section{THEM IN THEIR COUNTRY}

Migrants create a delocalized transnation and as a diaspora they have a special bond with their homeland (Appandurai 2005). Currently in the era of globalization and commonly available access to the Internet, mobile telecommunications, satellite TV, and cheap airlines, maintaining regular contact with Poland has become much easier than 30 years ago.

When looking at the migration process [from other countries] or from Poland, initially it was economically motivated, then in many cases, a politically manifested opposition against the system. Nowadays, migration has become a matter of choice just like choosing a particular profession. There are no longer such dramatic consequences. I know that for example our friends, who came to Norway through refugee camps or the like, couldn't enter Poland for eight years, until they had received Norwegian citizenship. Now it's not a problem. So it's a far less dramatic decision. It's just like migrating from one workplace to another. You always have to bear some costs of your decision, but you do it for a reason (Jakub).

Migrations are a matter of personal development, not related to morality, as they were defined in the past. Migration was seen as a refusal to take up responsibilities of one's national group, which gives an individual an ontological dimension and imposes a specific system of norms and sanctions. Therefore, it was to provoke moral degeneration and undesirable transformation of personality (Garapich 2010). Moreover, dramatic reasons to migrate generate close attachment to the concept of homeland (Appandurai 2005) and often lead to its idealization. For political migrants of the 1980s a more or less obligatory emigration from the country was a traumatic experience, one which determined their attitude towards the homeland. Many representatives of this migration period who settled in Norway in political protest against the communist regime had spent some time in Polish prisons, which gave their memories a form of ethos related to fighting for independence. While living in Norway, they cultivated their Polishness and the image of the forsaken motherland. When after 1989 they had a chance to visit Poland, it was hard for them to recognise the country and, most of all, accept the transformation of Poles' mentality.

I realized that so many things had changed that I couldn't find myself in Poland. I didn't know the wheres and hows. I got to know that you must give a bribe here, a bribe there, but I didn't have the foggiest idea how to do it (Ewa).

In Poland they can't understand us. Anyway, there's a different kind of stability. We are more even-tempered in some areas and lack this anxiety. Of course we have much more stable living conditions, we don't have to fight everyday with an everyday problem. And people look at us and think "oh yes, a totally different class, different people, different... What to talk about with them if they don't understand us". That was a bit disappointing and... we are different. We're them/ the other. Maybe we don't stand out from the crowd, maybe our language isn't so bad that someone could say that we've been living abroad for a long time, but nonetheless we do have a different mentality (Wojciech). 
After such a long absence in the country I feel neither here nor there, I don't consider myself Norwegian. Norway isn't my country, but in Poland... Even after the death of my mother-in-law when I had to settle things in different offices, I sometimes asked myself"does this woman speak Polish or Chinese?" I had major problems [...] There are so many changes, so many new things, and a new mentality. I left Poland with a different mentality, now the new generation lives differently (Jolanta).

So now where am I supposed to be? Neither Norwegian nor Polish (Marek S.).

Despite an initial urge to return to Poland, only some of them have managed to achieve this goal. The others felt like foreigners among people who spoke the same language but had different values and their lives were governed by strange norms. The migrants did not take into account the fact that the nation undergoes constant transformation in the process of further development. Especially when such a dramatic and revolutionary system change took place as it did in 1989.

Current migrations do not have such dramatic underpinnings. In a place of rapid change and breakup, one can experience an evolutionary process of recognizing the reality, learning and taming the space with a possibility of return to the country within a hand's reach (Garapich 2010). However, the Polish migrants are unwilling to come back. Such act is seen as failure since there is an informal obligation of achieving material success abroad, mainly induced by one's expectations and the family left in Poland (Boski 2010).

I say: "Why don't you return to Poland? You have or had a job there, didn't you?" "I had". "You earned money, didn't you?"

"Yeah, he says - you can say that. I'm ashamed to come back to Poland. I'm ashamed to return there without money" (Wojciech).

Migrants also do not see any prospects for the future in Poland, disappointed by the fact that the other society treats them better and gives them more chances of development than their own (Toruńczyk-Ruiz 2010). However, those that plan a return try to maintain regular contact with the country so that the social environment, in which they are going to live again, will not be the other, and they will be able to live as us in our country.

\section{CONCLUSION}

From the moment of joining the European Union in 2004 Poland has become a main exporter of labour force to the wealthy countries of Europe. Thanks to the work of Polish migrants Ireland, Great Britain and Norway have noted a significant boost to their economies. Due to poor integration, creating closed communities and, in many cases, lack of intercultural experience, since for many Poles departure to a new job was the first experience abroad, the migrants have developed a very clear us and them distinction (Toruńczyk-Ruiz 2010). The problems in deciphering culture codes are the main reason why Poles decide to stay in closed enclaves, where everything is clear and understandable. As a consequence of 
the contraculturation process (Gajda 2008), they treat Norwegian society with animosity and distrust, whereas their own positive national traits create a highly idealized image of Polish culture.

One cannot omit the fact that the us-them relations, which are still maintained having passed the contraculturation stage, usually appearing at the beginning of the migration process, mainly relate to people with a highly traditionalistic worldview, unwilling to accept otherness (Boski 2008).

It is worth noticing that not all Polish migrants live within their ethnic groups. The phenomenon described above can be found mainly in large agglomerations such as Oslo or Stavanger, where the industrial sector attracts large communities of immigrant workers. However, many Poles live in small villages scattered across the country, which lack large ethnic groups of Polish origin. Thus the migrants are forced to interact with Norwegian society.

Most Polish immigrants living in Norway are satisfied with their lives in the new reality and do not plan on changing this in the near future. They usually work in professions unattractive to the natives and do not aspire to higher positions; therefore, they do not pose a threat to Norwegians. Poles and Norwegians mutually feel as the other, however, this otherness does not carry any sense of threat. In addition, Poles in Norway are not seen as much the other as the larger and more culturally distant migrants from the countries of Africa, Asia or the Middle East. Especially now when the country is populated by whole migrant families, the native citizens expect that the Polish immigrants in the second and third generation, with a proper integration policy introduced by the government, will blend in with the Norwegian society and eventually become $u s$.

\section{BIBLIOGRAPHY}

Adamowska, Monika. 2011. Norwegia chce odzyskać mała Nicolę. Sprawa w squdzie, "Gazeta Wyborcza", www.wyborcza.pl [22.10.2011].

Andreassen, Pål. 2012. Tatt med sigaretter, "Moss Avis", www.moss-avis.no [08.02.2012].

Appandurai, Arjun. 2005. Nowoczesność bez granic. Kulturowe wymiary globalizacji, Kraków: Universitas.

Barnevernet. 2012. Barnevernloven, www.barnevernet.no [26.02.2012].

Barth, Fredrik. 1969. Ethnic Groups and Boundaries. The Social Oganization of Culture Difference, Oslo: Universitetsforlaget.

Bartmiński, Jerzy. 2007. Opozycja swój/obcy a problem językowego obrazu świata, "Etnolingwistyka" 19: 35-59

Bauman, Zygmunt. 2000. Ponowoczesność jako źródto cierpień, Warszawa: Sic!

Benedyktowicz, Zbigniew. 2000. Portrety „obcego”. Od stereotypu do symbolu, Kraków: Wydawnictwo Uniwersytetu Jagiellońskiego.

Biłas-Henne, Monika. 2011. Sieci spoleczne i wsparcie społeczne studentów programu ERASMUS, in: Waldemar Martyniuk (eds), Internacjonalizacja studiów wyższych, Warszawa: Fundacja Rozwoju Systemu Edukacji, pp. 171-192. 
Bokszański, Zbigniew. 1997. Stereotypy a kultura, Wrocław: Leopoldinum.

Boski, Paweł. 2008. Tożsamość kulturowa, in: Piotr Oleś and Anna Batory (eds), Tożsamość i jej przemiany a kultura, Lublin: Wydawnictwo KUL, pp. 96-118.

Boski, Paweł. 2010. Psychologia migracji i akulturacji w społeczeństwie wielokulturowym, in: Halina Grzymała-Moszczyńska, Anna Kwiatkowska and Joanna Roszak (eds), Drogi i rozdroża. Migracje Polaków w Unii Europejskiej po 1 maja 2004 roku, Kraków: Zakład Wydawniczy Nomos, pp. 107-132.

Braathen, Frøydis. 2011. Disse yrkesgruppene trenger Norge, "Aftenposten”, www.aftenposten.no, [25.05.2011].

Bystroń, Jan. 1980. Tematy, które mi odradzano, Warszawa: PIW.

Dębowska, Olga. 2007. Migracje - wyniki aktualnych badań i analiz, Kraków: Wojewódzki Urząd Pracy w Krakowie.

Eriksen, Hanne. 2012. Smugling og falske id-papirer, "Halden Arbeiderblad", www.ha-halden.no [05.02.2012].

Friberg, Jon and Guri Tydlum. 2007. Polske migranter i Oslo-en pilotstudie, in: Jon Friberg and Guri Tydlum (eds), Polonia i Oslo. En studie av arbeids - og levekaar blant polakker $i$ blant polakker $i$ hovedstastadsomraadet, Oslo: Fafo-rapport, pp. 7-17.

Gajda, Janusz. 2008. Antropologia kulturowa. Wprowadzenie do wiedzy o kulturze, Kraków: Oficyna Wydawnicza Impuls.

Garapich, Michał. 2010. Chłopi i żołnierze, budowlańcy i pijacy. Dominujacy dyskurs migracyjny, jego kontestacje oraz konsekwencje dla konstruowania polskiej grupy etnicznej $w$ wielokulturowym Londynie, in: Halina Grzymała-Moszczyńska, Anna Kwiatkowska and Joanna Roszak (eds), Drogi i rozdroża. Migracje Polaków w Unii Europejskiej po 1 maja 2004 roku, Kraków: Zakład Wydawniczy Nomos, pp. 35-54.

Giddens, Anthony. 2001. Nowoczesność i tożsamość. „Ja” i społeczeństwo w epoce późnej nowoczesności, Warszawa: Wydawnictwo Naukowe PWN.

Główny Urząd Statystyczny Departament Badań Demograficznych. 2011. Informacja o rozmiarach i kierunkach emigracji z Polski w latach 2004-2010, Warszawa: GUS.

Grzymała-Kazłowska, Aleksandra. 2007. Konstruowanie ,,innego”. Wizerunki imigrantów w Polsce, Warszawa: Wydawnictwa Uniwersytetu Warszawskiego.

Gulldahl, Gudrun. 2012. Jobbet 102 timer i uka, "iTromso", www.itromso.no [17.01.2012].

Kłos, Bożena. 2006. Migracje zarobkowe Polaków do krajów Unii Europejskiej, in: "Infos. Zagadnienia społeczno-gospodarcze",

http://www.skpnszz.org/downloads/2007r/Opracowania/infos_002\%5B1\%5D.pdf [17.01.2012].

Kulas, Bogdan. 2012. bogdankulas.blog.onet.pl [26.02.2012].

Liebkind, Karmela. 2006. Ethnic Idetnity and Acculturation, in: David Sam and John Berry (eds), The Cambridge Handbook of Acculturation Psychology, Cambridge: Cambridge University Press, pp. 78-96.

Mazur, Zbigniew and Irmina Wawrzyczek. 2010. Polak jako inny w brytyjskich dyskursach prasowych, 2002-2007, in: Halina Grzymała-Moszczyńska, Anna Kwiatkowska and Joanna Roszak (eds), Drogi i rozdroża. Migracje Polaków w Unii Europejskiej po 1 maja 2004 roku, Kraków: Zakład Wydawniczy Nomos, pp. 70-88. 
Michalsen, Ingrid. 2011. Vestas sparket faste ansatte, beholdt midlertidige ansatte, "Aftenposten", www.aftenposten.no [7.12.2011].

Mucha, Janusz. 1999. Badania stosunków kulturowych z perspektywy mniejszości, in: Janusz Mucha (ed.), Kultura dominujaca jako kultura obca. Mniejszości kulturowe a grupa dominujaca w Polsce, Warszawa: Oficyna Naukowa, pp. 11-25.

Mucha, Janusz and Wojciech Olszewski (eds). 1997. Dylematy tożsamości europejskich pod koniec drugiego tysiaclecia, Toruń: Wydawnictwo UMK.

Nederba, Rolen. 2012. Oelen-verft maa rydde opp, "Aftenposten", www.aftenposten.no [17.01.2012].

Norsk statistisk sentralbyrå. 2009. Netto innvandring, etter land. 1966-2011, www.ssb.no [17.01.2012].

Norsk statistisk sentralbyrå. 2012a. Framleis høg innvandring og folkevekst, www.ssb.no [17.01.2012].

Norsk statistisk sentralbyrå. 2012b. Fleire tilsette og fleire barn i barnevernet, www.ssb.no [17.01.2012].

Nygaard, Fridtjof. 2011. Sa opp nordmenn - beholdt polakker, "E24!", www.e24.no [7.12.2012].

Obrębski, Józef. 1936. Problem grup etnicznych $w$ etnologii i jego socjologiczne ujęcie, "Przegląd socjologiczny" 4: 1-2.

Oddvin, Aune. 2011. Mener polske arbeidere er bedre, "NRK", www.nrk.no [7.12.2011].

Oleś, Piotr. 2008. O różnych rodzajach tożsamości oraz ich stałości i zmianie, in: Piotr Oleś and Anna Batory (eds), Tożsamość i jej przemiany a kultura, Lublin: Wydawnictwo KUL, pp. 41-84.

Olsen, Olav. 2012. Demonstrer mot norsk barnevernsak i India, “Aftenbladet”, www.aftenbladet.no [19.02.2012].

Phinney, Jean. 2003. Ethnic Identity and Acculturation, in: Kevin Chun, Pamela Ballas-Organista and Gerardo Marin (eds), Acculturation: Advences In Theory, Mearsurment, And Applied Research, Washington: APA, pp. 63-81.

Renda, Ola. 2010. Wyparci przez tanich Polaków, www.mojanorwegia.pl [6.10.2010].

Skogsrad, Sylwia. 2012. Kto finansuje księdza Natanka?, www.wp.pl [15.02.2012].

Sokół-Rudowska, Monika. 2010. Polska współczesna emigracja zarobkowa w Norwegii, in: Polacy w Norwegii (XIX-XXI w.). Wybór materiałów źródłowych; Kraków: Archiwum Państwowe w Krakowie.

Sokół-Rudowska, Monika. 2011. Polacy wśród śniegów północy. Zjawisko polskiej migracji do Norwegii na przestrzeni dwustu lat, "Studia Humanistyczne AGH” 2: 101-113.

Tiersland, Jonas. 2012. Maa ansette polakker, www.e24.no [7.12.2012].

Toruńczyk-Ruiz, Sabina. 2010. Na obczyźnie Polak Polakowi wilkiem: zanik poczucia wspólnoty i patriotyzmu? Współcześni polscy migranci w Holandii, in: Halina Grzymała-Moszczyńska, Anna Kwiatkowska and Joanna Roszak (eds), Drogi i rozdroża. Migracje Polaków w Unii Europejskiej po 1 maja 2004 roku, Kraków: Zakład Wydawniczy Nomos, pp. 133-145.

Trygstad, Sissel, Kristine Nergaard, Kristin Alsos and Øyvind Berge. 2011. Til renholdets pris, Oslo: Fafo-rapport.

Witoszek, Nina. 2012. Godhetens tyranni, “Aftenposten”, www.aftenposten.no [7.12.2012]. 
Znaniecki, Florian. 1931. Studia nad antagonizmem do obcych, "Przegląd Socjologiczny" 2: $158-209$.

The interview whose fragments have been used in the article, come from projects conducted mainly by Opplandsarkivet avdeling Maihaugen in Lillehammer: Arkivdokumentasjon av nyere innvandring til Oppland, Poles in Norway (1 $19^{\text {th }}-21^{\text {th }}$ C.). Selection of materials, Polish Political Exile 1981 to Norway.

\section{SWOI POŚRÓD OBCYCH. NA PRZYKŁADZIE WSPÓŁCZESNEJ POLSKIEJ EMIGRACJI DO NORWEGII}

Od momentu wstąpienia Polski do Unii Europejskiej w 2004 roku zaobserwować można masową migrację Polaków za granicę głównie w celach zarobkowych. Badania statystyczne wykazują, że począwszy od tego momentu z Polski wyjechało około dwóch milionów obywateli (Główny Urząd Statystyczny 2011). Jednym z krajów docelowych polskich migrantów była Norwegia. Polacy mieszkający i pracujący w tym kraju tworzą dosyć zamknięte grupy etniczne, głównie ze względu na nieznajomość języka nie tylko norweskiego, ale i angielskiego. Społeczności te starają się na nowo zbudować swoją tożsamość w nowym kraju, opierając się na tradycjach i kodach kulturowych przywiezionych ze sobą z Polski, a także przeciwstawnych wartościach swój-obcy. W tym wypadku swoimi są członkowie mniejszości polskiej w Norwegii, którzy postępują zgodnie z normami przyjętymi przez grupę, a antagonistami Norwegowie, w konfrontacji z którymi można potwierdzić własne wzorce i idee. Należy jednak pamiętać, że nie wszyscy Polacy żyją w swoich grupach etnicznych. Względna jednolitość kulturowa Polski pozwala na stosunkowo szybkie odnalezienie własnej grupy na migracji i określenie swojej pozycji w niej. Jednak przebywanie poza granicami ojczyzny sprawia, że własna tożsamość zmienia się, ulegając obcym wpływom. Podobnie ma się sprawa z tożsamością obcego, którego obraz jest również zmienny w zależności od sytuacji. Wewnątrz społeczności polskich migrantów, początkowo uważanych za bezwzględnie swoich, z czasem dostrzec można kategoryzację i gradualizację swojskości. Wielu Polaków, najczęściej tych słabo wykształconych, świadomie wybiera izolację od kultury kraju przyjmującego, chcąc tym sposobem zachować własną kulturę. Jednocześnie, sprowadzając swoją rodzinę i przyjaciół z Polski, starają się dokonać reprodukcji utraconej lokalności.

Słowa kluczowe: migracja, Polacy, Norwegia, swój-obcy, integracja 